\title{
Neuroprotective Properties of 4-Aminopyridine
}

Michael Dietrich, PhD, Hans-Peter Hartung, MD, PhD, FRCP, and Philipp Albrecht, MD

Neurol Neuroimmunol Neuroinflamm 2021;8:e976. doi:10.1212/NXI.0000000000000976

Correspondence

Dr. Albrecht

phil.albrecht@gmail.com

\section{Abstract}

As an antagonist of voltage-gated potassium (Kv) channels, 4-aminopyridine (4-AP) is used as symptomatic therapy in several neurologic disorders. The improvement of visual function and motor skills and relieve of fatigue in patients with MS have been attributed to 4-AP. Its prolonged release formulation (fampridine) has been approved for the symptomatic treatment of walking disability in MS. The beneficial effects were explained by the blockade of axonal $\mathrm{Kv}$ channels, thereby enhancing conduction along demyelinated axons. However, an increasing body of evidence suggests that 4-AP may have additional properties beyond the symptomatic mode of action. In this review, we summarize preclinical and clinical data on possible neuroprotective features of 4-AP.

From the Department of Neurology (M.D., H.-P.H., P.A.), Medical Faculty, Heinrich-Heine University Düsseldorf, Düsseldorf, Germany; and Brain and Mind Center (H.-P.H.), University of Sydney, Australia.

Go to Neurology.org/NN for full disclosures. Funding information is provided at the end of the article.

The Article Processing Charge was funded by the Open Access Fund Heinrich-Heine University.

This is an open access article distributed under the terms of the Creative Commons Attribution-NonCommercial-NoDerivatives License 4.0 (CC BY-NC-ND), which permits downloading and sharing the work provided it is properly cited. The work cannot be changed in any way or used commercially without permission from the journal. 


\section{Glossary}

3,4-DAP = 3,4-diaminopyridine; 4-AP = 4-aminopyridine; $\mathbf{B D N F}=$ brain-derived neurotrophic factor; $\mathbf{E A E}=$ experimental autoimmune encephalomyelitis; EAEON = experimental optic neuritis; EMA = European Medicines Agency; Kv channel = voltage-gated potassium channel; $\mathbf{M N}$ = motor neuron; $\mathbf{M O G}=$ myelin oligodendrocyte glycoprotein; MSWS-12 = 12-Item Multiple Sclerosis Walking Scale; NFAT = nuclear factor of activated T-cells; OCT = optical coherence tomography; PGIC = Patient Global Impression of Change; SR-4-AP = sustained-release formulation of 4-AP; T25FW = Timed 25 Foot Walk Test; TUG $=$ Timed Up and Go.

\section{4-Aminopyridine in Neurologic Disease}

Aminopyridines are a group of monoamino and diamino derivatives of pyridine, which inhibit voltage-gated potassium $(\mathrm{Kv})$ channels. Especially, the 2 broad-spectrum potassium channel blockers 4-aminopyridine (4-AP) and 3,4-diaminopyridine (3,4$\mathrm{DAP})$ have been used as investigational new substances in various neurologic diseases. Despite the fact that 3,4-DAP is a more potent antagonist of potassium channels, 4-AP crosses the bloodbrain barrier more readily ${ }^{1}$ and was clinically superior in patients with MS, particularly for improving visual function, ${ }^{2}$ fatigue, ${ }^{3}$ cognition, ${ }^{4}$ and walking speed. ${ }^{1}$ In addition, 4-AP has been reported to facilitate neural conduction in neurologic diseases other than MS. ${ }^{5,6}$

In healthy axons, the channels Kv1.1 and Kv1.2 are clustered near the nodes of Ranvier. ${ }^{7}$ These channels become exposed after demyelination and migrate through the demyelinated segment. At the same time, expression of these channels is increased several fold. ${ }^{8}$ This misdirected redistribution of the Kv channels impairs the transmission of action potentials, leading to permanent disability. 4-AP blocks these exposed potassium channels and therefore enhances signal transduction., ${ }^{9,10}$ The Kv1.3 channel was discovered in human T-cells, ${ }^{11}$ was found to be highly expressed on inflammatory infiltrates in the MS brain, ${ }^{12}$ and is expressed on macrophages, microglia, and effector memory $\mathrm{T}$ cells. ${ }^{13}$ Selective and nonselective Kv1.3 channel blockers might thereby provide immunomodulatory properties by inhibiting cell proliferation and proinflammatory cytokine secretion. ${ }^{14}$ Studies before 2009 failed to establish 4-AP as a symptomatic treatment for MS because drug blood levels in patients were unpredictable, with excessive doses being associated with the risk of epileptic seizures and impaired consciousness. ${ }^{15-18}$ Therefore, fampridine, the prolonged release formulation of 4-AP was developed and has subsequently been approved for the symptomatic treatment of walking disability in MS. ${ }^{19-23}$ Interestingly, more recently, an increasing body of evidence suggests that besides these widely acknowledged symptomatic effects, 4-AP may have additional protective properties.

\section{Evaluation of 4-AP Using In Vitro Models}

In vitro, neuroprotective effects of 4-AP have been observed in numerous models. When motor neurons ( $\mathrm{MNs}$ ) differentiated from induced pluripotent stem cells of patients with amyotrophic lateral sclerosis carrying mutations of the FUS and SOD1 gene were exposed to 4-AP, ion-channel imbalances were redressed, neuronal activity levels raised, endoplasmatic reticulum stress diminished, and caspase activation attenuated. The mutant MNs showed lower sodium currents and $\mathrm{Na}^{+} / \mathrm{K}^{+}$ ratios, which may at least in part be the reason for their hypoexcitability. This was reversed after 4-AP treatment, which led to decreased potassium currents and restored spontaneous activity patterns and synaptic input in the MNs. ${ }^{24} 4-\mathrm{AP}$ treatment reduced the release of proinflammatory mediators from human microglia challenged with amyloid beta and protected cultured rat hippocampal neurons bathed in supernatants from amyloid beta treated microglia. ${ }^{25} \mathrm{~A}$ 4-AP derivative reportedly reduced $\alpha$-synuclein accumulation, oxidation, inflammation, and Rho kinase activation in an in vitro model of Parkinson disease. ${ }^{26}$ Other in vitro studies reported that 4-AP increased cAMP response element-binding protein phosphorylation provided protection from cellular stress by glutamate, NMDA, and 3-nitropropionic acid exerted on rat neonatal cerebellar granule neurons. Glutamate lead to a decreased viability also in cells preconditioned with 4-AP but with no significant activation of caspase-3. These observations suggested that 4-AP is primarily effective against necrotic excitotoxicity. ${ }^{27}$ It was also shown to protect primary neuronal cultures from oxygenglucose deprivation or ouabain/DL-threo- $\beta$-benzyloxyaspartic acid toxicity. ${ }^{28}$

\section{Preclinical In Vivo Studies on 4-AP}

Several studies have investigated the protective effects of 4-AP in various disease models (table 1). In nerve crush models of peripheral nerve damage, prophylactic and early 4-AP treatment prompted recovery of nerve conduction velocity, promoted remyelination, and augmented the axonal area. The latter observations were explained by effects similar to those appearing after electrical stimulation, for instance, elevations in neuronal brain-derived neurotrophic factor (BDNF) levels. ${ }^{29}$ In a model of Alzheimer disease, injection of amyloid-beta into the hippocampus of Sprague Dawley rats induced neuronal damage and heightened microglial activation. Daily administration of $1 \mathrm{mg} / \mathrm{kg} 4-\mathrm{AP}$ was found to suppress microglial activation and provided neuroprotection. This was attributed to 4-AP's ability to block the noninactivating outwardly rectifying $\mathrm{K}+$ current in activated microglia and reduce cellular production of proinflammatory cytokines. ${ }^{25}$ Investigations using an in vivo 
Table 1 Summary of Preclinical Studies on 4-AP With Main Findings

\begin{tabular}{|c|c|c|c|}
\hline Model & Animal & Main finding 4-AP treatment & Study \\
\hline Sciatic nerve crush & C57BL6 mice & Recovery of nerve conduction velocity and promoted remyelination. & Tseng et al. ${ }^{29}$ \\
\hline $\begin{array}{l}\text { Traumatic peripheral } \\
\text { nerve injury }\end{array}$ & C57BL6 mice & $\begin{array}{l}\text { Recovery of nerve conduction velocity, promoted remyelination, and increased axonal } \\
\text { area. }\end{array}$ & Noble et al. ${ }^{53}$ \\
\hline Alzheimer disease & $\begin{array}{l}\text { Sprague Dawley } \\
\text { rats }\end{array}$ & Suppression of microglial activation and exhibition of neuroprotection. & $\begin{array}{l}\text { Franciosi } \\
\text { et al. }^{25}\end{array}$ \\
\hline $\begin{array}{l}\text { Hippocampal } \\
\text { neurotoxicity }\end{array}$ & Std-ddY mice & $\begin{array}{l}\text { Neuroprotective effects and NMDA receptors might be relevant for 4-AP-mediated } \\
\text { protection. }\end{array}$ & Ogita et al. ${ }^{30}$ \\
\hline $\begin{array}{l}\text { Autoimmune } \\
\text { neuropathy }\end{array}$ & Lewis rats & Ameliorated clinical scores and improved electrophysiologic findings. & $\begin{array}{l}\text { Moriguchi } \\
\text { et al. }{ }^{31}\end{array}$ \\
\hline PLP $_{139-151}$ EAE & SJL mice & Improved clinical scores, T-cell activation, and Th1/17 polarization was attenuated. & $\begin{array}{l}\text { Moriguchi } \\
\text { et al. }{ }^{35}\end{array}$ \\
\hline$M \mathrm{GG}_{35-55} \mathrm{EAE}$ & C57BI/6] & Symptomatic but no disease modifying effects & Göbel et al. ${ }^{36}$ \\
\hline MOG $_{35-55}$ EAE & $\begin{array}{l}\text { Kv3.1 knock out } \\
\text { mouse }\end{array}$ & Inhibited T-cell activation, ameliorated axonal demyelination, and degeneration. & $\begin{array}{l}\text { Jukkola } \\
\text { et al. }{ }^{34}\end{array}$ \\
\hline $\mathrm{MOG}_{35-55} \mathrm{EAE}$ & C57BI/6] & $\begin{array}{l}\text { Reduced retinal degeneration and improved visual function, less demyelination, and } \\
\text { involvement of NFAT pathway }\end{array}$ & $\begin{array}{l}\text { Dietrich } \\
\text { et al. }{ }^{37}\end{array}$ \\
\hline
\end{tabular}

Abbreviations: 4-AP = 4-aminopyridine; EAE = experimental autoimmune encephalomyelitis; $\mathrm{Kv}$ = voltage-gated potassium; NFAT = nuclear factor of activated T-cells.

model of kinate-induced hippocampal neurotoxicity revealed robust neuroprotective effects of 4-AP that could be abrogated by the noncompetitive NMDA receptor antagonist MK- 801 and the adenosine A1 antagonist 8-cyclopenthyltheophylline. These observations suggest that NMDA receptors are relevant for 4-AP mediated protection in this model. ${ }^{30}$ In an animal model of autoimmune neuropathy in Lewis rats, 4-AP ameliorated the clinical severity and pathologic electrophysiologic findings. The authors suggested that axonal protection was provided by blocking sodium-mediated inward currents in the early phase because high membrane potentials in the acute phase of inflammation may be neurotoxic. In the chronic phase, nervous conduction was potentially improved by blocking potassium-mediated outward currents. ${ }^{31}$

In experimental autoimmune encephalomyelitis (EAE), a model of immune-mediated CNS inflammation replicating cardinal features of MS, Kv channel blockade has been reported to inhibit T-cell activation, potentially by blocking of channels of the Kv1.3 subfamily ${ }^{32,33}$ and attenuated axonal demyelination and degeneration by acting on the $\mathrm{K}_{\mathrm{v}} 3.1$ channel on astroglia, potentially inducing the BDNF signalling. ${ }^{34}$ In proteolipid protein-induced EAE in SJL mice, 4-AP treatment significantly improved the clinical scores which was confirmed pathologically. Glial fibrillary acidic protein expression was observed to be downregulated in 4-AP-treated mice, and T-cell activation and Th1/17 polarization were mitigated. However, in the chronic, myelin oligodendrocyte glycoprotein (MOG) peptide-induced EAE model in C57BL/6 mice, 4-AP did not change the EAE course. ${ }^{35} \mathrm{An}$ other study also investigated the effects of 4-AP in a MOGEAE model in C57BL/6 mice and reported symptomatic but no disease modifying effects. Neither a prophylactic nor a therapeutic 4-AP treatment attenuated the severity of the clinical EAE course, whereas 4-AP treated animals showed improved mobility assessed by foot print and rotarod analysis. Demyelination of the spinal cord, neuronal damage, and MRI imaging of brain volume changes were unaltered. Proliferation, IL17, or IFN- $\gamma$ production of $\mathrm{CD} 4^{+} \mathrm{T}$-cells were also unaffected. ${ }^{36}$

More recently, we have demonstrated that apart from its symptomatic effects on enhancing neural conduction, 4-AP can prevent retinal neurodegeneration during MOG peptideinduced experimental optic neuritis (EAEON) in C5BL6 mice. ${ }^{37}$ Using in vivo optical coherence tomography (OCT) imaging, visual function testing, and histologic assessment, we observed a reduction in the extent of degeneration of inner retinal layers in models of EAEON, both for prophylactic and therapeutic 4-AP administration. In this model, 4-AP potentiated the effects of immunomodulatory treatment with the sphingosine-1-phosphate receptor modulator fingolimod, suggesting independent modes of action. It is reasonable to assume that this effect is not limited to fingolimod alone and applicable to 4-AP combined with other MS immunomodulatory drugs. In our study, optic nerve histology revealed that in contrast to fingolimod, 4-AP had no significant influence on microglial activation and/or infiltration of lymphocytes or macrophages, suggesting that the protective effects were not related to an anti-inflammatory mode of action. In line with this, 4-AP treatment did not interfere with EAE induction, validated by a $\mathrm{T}$-cell restimulation assay. Furthermore, we observed significant protection from retinal neurodegeneration under 4-AP treatment also in the noninflammatory optic nerve 
Table 2 Summary of Relevant Clinical Studies on 4-AP From 2007 Until Now

\begin{tabular}{|c|c|c|c|c|}
\hline Study & Phase & SR-4-AP dosing & Main findings & $\begin{array}{l}\text { Sample } \\
\text { size }\end{array}$ \\
\hline $\begin{array}{l}\text { Goodman et al., } \\
\text { MS-F201'19 }\end{array}$ & II & $\begin{array}{l}10-40 \text { mg twice daily, increasing in } \\
5 \text { mg increments weekly }\end{array}$ & Improvement in walking speed and of self-reported fatigue & 36 \\
\hline $\begin{array}{l}\text { Goodman et al., } \\
\text { MS-F202 }\end{array}$ & II & 10,15, or $20 \mathrm{mg}$ twice daily & Improvement in walking speed and muscle strength & 206 \\
\hline $\begin{array}{l}\text { Goodman et al., } \\
\text { MS-F20321 }\end{array}$ & III & $10 \mathrm{mg}$ twice daily & $\begin{array}{l}35 \% \text { responders; improvement in walking speed, muscle strength, } \\
\text { MSWS- } 12\end{array}$ & 301 \\
\hline $\begin{array}{l}\text { Goodman et al., } \\
\text { MS-F204 }\end{array}$ & III & $10 \mathrm{mg}$ twice daily & $42.9 \%$ responders; improvement in walking speed & 239 \\
\hline $\begin{array}{l}\text { Hupperts et al., } \\
\text { MOBILE }^{23}\end{array}$ & II & $10 \mathrm{mg}$ twice daily & Improvement in MSWS-12, TUG speed and PGIC & 132 \\
\hline $\begin{array}{l}\text { Macdonell et al., } \\
\text { ENABLE }^{52}\end{array}$ & IV & $10 \mathrm{mg}$ twice daily & $\begin{array}{l}\text { Improvements in the SF-36 PCS, SF-36 MCS, MSIS-29, PRIMUS ALS, EQ- } \\
\text { 5D-3L, and WPAI-SHP activity impairment }\end{array}$ & 901 \\
\hline $\begin{array}{l}\text { Hobart et al., } \\
\text { ENHANCE }\end{array}$ & III & $10 \mathrm{mg}$ twice daily & Improvement in MSWS-12, TUG speed, MSIS-29, and PGIC & 646 \\
\hline
\end{tabular}

Abbreviations: EQ-5D-3L = EuroQol-5 Dimension 3-level version; MSWS-12 = 12-Item MS Walking Scale; PGIC = patient global impression of change, MSIS-29 = 29-Item MS Impact Scale SF-36 PCS = 36-Item Short-Form physical component summary; PRIMUS ALS = Patient-Reported Indices for MS activity limitations scale; SF-36 MCS = 36-Item Short-Form mental component summary; TUG = timed up and go; WPAI-SHP = Work Productivity and Activity Impairment, Specific Health Problem.

crush model, whereas, here, fingolimod had no effect. Interestingly, in vitro, 4-AP treatment failed to directly protect retinal ganglion cells. Instead, histology and in vitro experiments indicated 4-AP-mediated stabilization of myelin and oligodendrocyte precursor cells. This effect was associated with increased calcium influx and nuclear translocation of the nuclear factor of activated T-cells (NFAT). It has previously been shown that 4-AP regulates calcium homeostasis by elevating inositol trisphosphate levels and thereby causing calcium release from intracellular calcium stores. ${ }^{38}$ However, additional studies on 4-AP in demyelinating models, for instance, cuprizone-treatment or transgenic mouse models with inducible oligodendrocyte ablation might be helpful to confirm these conclusions. Existing studies in animal models of demyelination mainly focus on the capacity of 4-AP to restore the action potential but lack further investigations of oligodendroglial cells (figure). ${ }^{39}$

It is important to mention that the doses needed to obtain these effects in vitro are approximately 100-1,000x higher than the concentration achieved in patients. ${ }^{39}$ Therefore, additional or other mechanisms might be relevant for the observations made in vivo and in vitro. These include but are not limited to a diminished energy dissipation of demyelinated axons because of blockage of potassium leakage and stronger protective and reparative capacities in the brain indirectly resulting from increased mobility and greater exercise.

Moreover, immunomodulatory mechanisms of 4-AP cannot be ruled out especially because reduced $\mathrm{T}$-cell activation and Th1/17 polarization have been demonstrated in PLP-induced EAE in SJL mice. ${ }^{35}$ In addition, preclinical studies of other disease models found an attenuated activation and reduced release of proinflammatory mediators by microglia. ${ }^{25}$ These controversial results highlight the diverse pathologic mechanisms of the different animal models, where immune cells are more or less susceptible to treatment strategies. The discrepancies between our results and previous reports of only symptomatic effects in MOG peptide-induced EAE in C57BL6 mice ${ }^{35,36}$ may at least in part be explained by (1) differences in dosing because others used doses of $100 \mu \mathrm{g}$ and $600 \mu \mathrm{g} / \mathrm{mouse} /$ day, whereas we administered $250 \mu \mathrm{g} / \mathrm{mouse} / \mathrm{d}$; (2) treatment duration (40,60, and 90 days by Göbel et al., ${ }^{36}$ Moriguchi et al., ${ }^{35}$ and Dietrich et al., ${ }^{37}$ respectively); and (3) amount of MOG used for immunization because we used $200 \mu \mathrm{g}$ MOG per mouse, whereas others used only $100 \mu \mathrm{g}$ MOG per mouse. Recent research focuses on the role of gut microbiota in influencing induction and severity of EAE by altering the balance of effector and regulatory $\mathrm{T}$ and $\mathrm{B}$ cells. ${ }^{40-42}$ The microbiome of the rodents may differ between the animal facilities resulting in differences of EAE severity, course, and possibly even response to therapeutics. Taken together, these factors could account for the heterogeneity in study results.

\section{Clinical Approach on 4-AP in Patients With MS}

Several clinical trials since the 1980s already suggested beneficial effects of 4-AP in people with MS. Among others, they identified improvement in motor ${ }^{40-42}$ and visual functions ${ }^{40-44}$ and fatigue. ${ }^{45-47}$ However, study limitations, absence of a homogeneous study design, and small patient numbers prohibited approval of 4-AP by the regular authorities and lead to an off-label use for more than 3 decades. ${ }^{48}$ On the other hand, some of these studies facilitated the development of the sustained-release formulation (SR-4-AP or fampridine) because they found the plasma levels of the original immediate-release compound to be inconsistent and unpredictable. The first clinical study with SR-4-AP was 


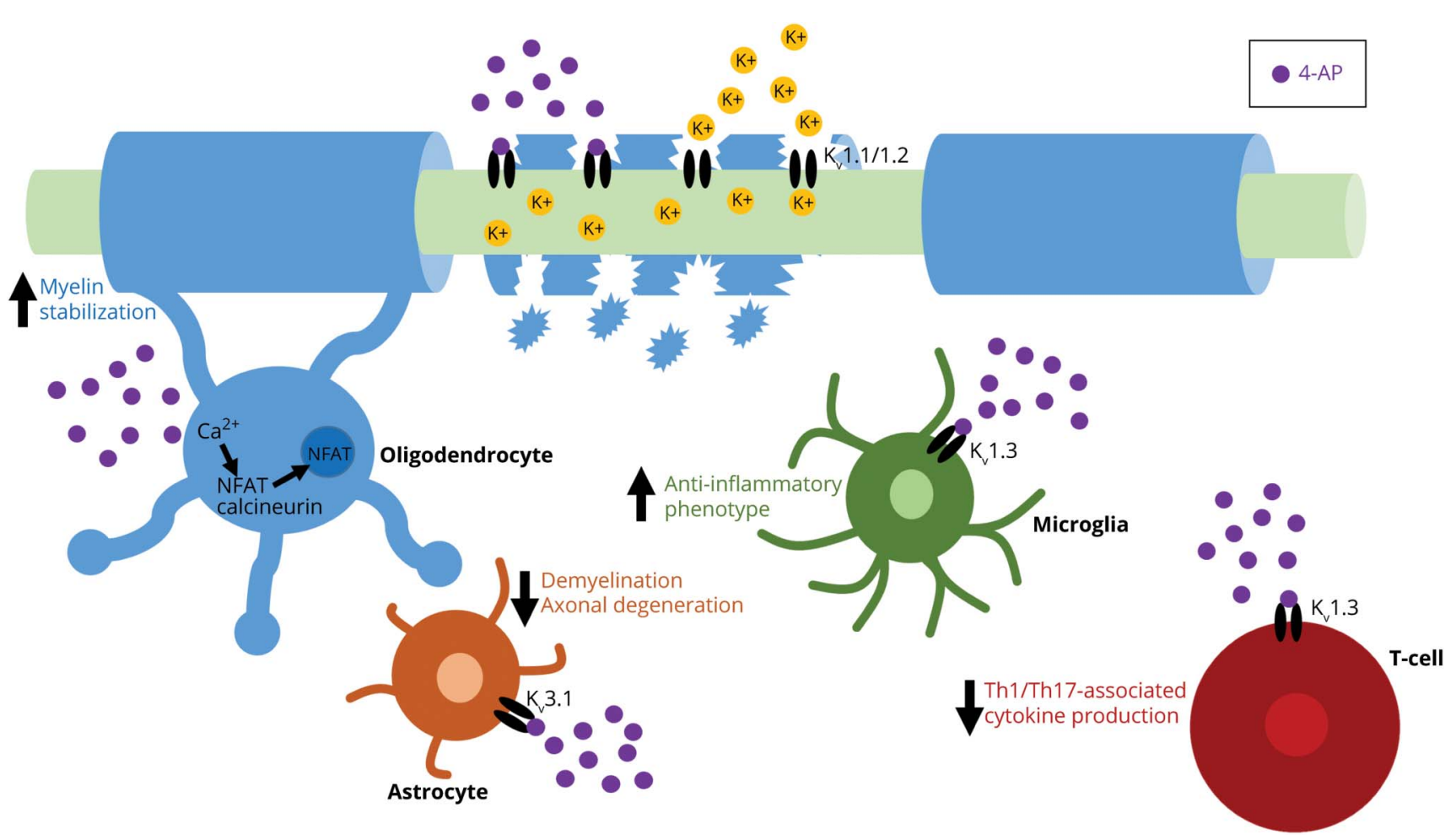

4-AP blocks potassium channels and therefore enhances signal transduction of the axon. ${ }^{9,10}$ Potential immunomodulatory effects may be exerted by $\mathrm{K}_{\mathrm{v}} 1.3$ channels expressed by microglia ${ }^{25}$ and T-cells. ${ }^{35}$ The Kv3.1 channel on astrocytes might be targeted by 4 -AP to suppress demyelination and axonal degenerating. ${ }^{34}$ In another preclinical study, 4-AP stabilized myelin via the NFAT pathway. ${ }^{39}$ 4-AP = 4-aminopyridine; NFAT = nuclear factor of activated T-cells.

performed in 1997 by Schwid et al., ${ }^{49}$ demonstrating a significant amelioration of walking speed and a trend toward improvement of muscle strength.

The extended release technology system was developed by Elan Pharmaceuticals. It used a so-called matrix drug absorption system, consisting of a proprietary polymer matrix that controls release by diffusion and erosion by gastrointestinal enzymes. This resulted in lower peak plasma drug levels and longer duration of action. ${ }^{48}$ Initially, SR-4-AP was tested in 4 trials. In 2007, Goodman et al. ${ }^{19}$ performed a dose-ranging trail in $5 \mathrm{mg}$ increments from 10 up to $40 \mathrm{mg}$, twice daily with 36 patients with MS. In the Timed 25 Foot Walk Test (T25FW), no significant change was observed, whereas a post hoc analysis converting the data into walking speed $(\mathrm{ft} / \mathrm{s})$ reached significance. In addition, an improvement of self-reported fatigue was observed. In a dose comparison trial in 2008 (randomized, double-blind, placebo-controlled), Goodman et al. ${ }^{20}$ recruited 206 patients, receiving placebo or doses of 10,15 , or $20 \mathrm{mg}$ twice daily. Again, post hoc analysis comparing improvement in walking speed found significantly better outcomes for all treatment groups individually and for all SR-4-AP-treated patients pooled compared with placebo. Muscle strength was improved for the 10-mg- and 15-mg-treated groups, but not for the $20 \mathrm{mg}$-treated group compared with the placebo subjects. In the 2 subsequent phase III clinical trials (21-week double-blind placebo-controlled randomized trial, 301 patients and 14-week double-blind placebo-controlled trial, 239 patients) with $10 \mathrm{mg}$ twice daily, the patients were divided in a responder group and a nonresponder group, defined by consistent improvement on T25FW. In both studies, the increase in walking speed was significant compared with the nonresponder or placebo group. Furthermore, there was an improvement in the 12-Item MS Walking Scale (MSWS-12) score for the responders. ${ }^{21,22}$

In an open-label extension trial of these studies, it was demonstrated that the clinical improvement was lost after drug withdrawal but returned 2 weeks after restarting the therapy of SR-4-AP. ${ }^{50}$ Ampyra/Fampyra, the tablet formulation of SR-4-AP received full approval by the Food and Drug Administration in January 2010 to improve walking in patients with MS, but only a conditional marketing authorization in 2011 from the European Medicines Agency (EMA). Based on the trials mentioned, the approval was subject to the provision to provide more long-term efficacy and safety data. Therefore, a phase II exploratory (MOBILE) and a phase III confirmatory study (ENHANCE) were initiated.

In the exploratory MOBILE study with 132 participants, an improvement of the Patient Global Impression of Change (PGIC), MSWS-12, and Timed Up and Go (TUG) speed was found. ${ }^{23}$ 
To evaluate the long-term efficacy and safety of SR-4-AP, the confirmatory ENHANCE study ( $10 \mathrm{mg}$ twice daily in $646 \mathrm{MS}$ patients) was performed. In addition to the improvements reported in the MOBILE trial, the authors found a significant improvement of SR-4-AP-treated patients on the 29-Item MS Impact Scale. ${ }^{51}$ The EMA afterward granted unconditional approval of SR-4-AP for the treatment of patients with MS with walking disability. The ENABLE phase IV observational study with 901 patients demonstrated that a treatment with SR-4-AP is beneficial for patients with MS by the means of self-perceived physical functioning and psychological health in a real-world setting ${ }^{52}$ (table 2 ).

Based on the promising preclinical data on protection from retinal neurodegeneration described above, our group performed a retrospective, multicenter OCT study to longitudinally compare retinal neurodegeneration between 52 patients on continuous 4-AP therapy and 51 controls that were matched for all relevant covariates using a predefined matching algorithm. In line with the experimental data, during concurrent 4-AP therapy, degeneration of the macular retinal nerve fiber layer was reduced over 2 years. However, these findings need to be corroborated in independent and ideally prospective cohort studies, especially because the effect size was low and the rates of peripapillary retinal nerve fiber layer and macular ganglion cell/inner plexiform layer thinning did not differ significantly between the groups. These discrepancies of a protective effect of 4AP only on the mRNFL, but neither in PRNFL nor in mGCIPL, is not easily be explained. It is important to mention that because 4AP is only licensed for improving walking disability in patients with EDSS 3.5-5, the change rates analyzed were investigated in later stages of disease and without acute optic neuritis. In such a setting, only very subtle retinal changes occur, and large cohorts would be required to detect treatment effects. Therefore, the retrospective study in patients was certainly not sufficiently powered to reliably detect protective treatment effects, and it does not come as a surprise that only one of the outcomes turned out positive. Possibly, the mRNFL was the most sensitive layer for the detection of treatment effects. ${ }^{37}$

In summary, a growing body of in vivo evidence suggests that 4-AP, in addition to its well-known symptomatic effects, by preventing neurodegeneration can modify the disease course of EAEON and possibly even patients with MS. Preliminary in vitro evidence implies the involvement of cellular calcium levels and the NFAT pathway, but further investigations are warranted to elucidate the exact molecular mechanisms underlying 4-AP's neuroprotective effect in immune-mediated inflammatory demyelination. These findings may have a marked impact on MS treatment strategies if confirmed in a prospective randomized controlled clinical trial.

\section{Study Funding}

The authors report no targeted funding.

\section{Disclosure}

M. Dietrich received speaker honoraria from Novartis and Merck. H.-P. Hartung has received fees for serving on steering and data monitoring committees from Bayer Healthcare, Biogen, Celgene BMS, CSL Behring, GeNeuro, MedImmune, Merck, Novartis, Octapharma, Roche, Sanofi Genzyme, TG Therapeutic sand Viela Bio, fees for serving on advisory boards from Biogen, Sanofi Genzyme, Merck, Novartis, Octapharma, and Roche and lecture fees from Biogen, Celgene BMS, Merck, Novartis, Roche, and Sanofi Genzyme. P. Albrecht received compensation for serving on Scientific Advisory Boards for Ipsen, Novartis, and Biogen; received speaker honoraria and travel support from Novartis, Teva, Biogen, Merz Pharmaceuticals, Ipsen, Allergan, Bayer HealthCare, Esai, UCB and Glaxo Smith Kline; and received research support from Novartis, Biogen, Teva, Merz Pharmaceuticals, Ipsen, and Roche. The MS Center at the Department of Neurology in Düsseldorf is supported in part by the Walter and Ilse Rose Foundation by grants to H.-P. Hartung. Go to Neurology.org/NN for full disclosures.

\section{Publication History}

Received by Neurology: Neuroimmunology \& Neuroinflammation July 1, 2020. Accepted in final form January 6, 2021.

\section{Appendix Authors}

\begin{tabular}{|c|c|c|}
\hline Name & Location & Contribution \\
\hline $\begin{array}{l}\text { Michael } \\
\text { Dietrich, PhD }\end{array}$ & $\begin{array}{l}\text { Department of } \\
\text { Neurology, Medical } \\
\text { Faculty, Heinrich-Heine } \\
\text { University Düsseldorf, } \\
\text { Düsseldorf, Germany }\end{array}$ & $\begin{array}{l}\text { Drafting/revision of the } \\
\text { manuscript for content, } \\
\text { including medical writing } \\
\text { for content; major role in } \\
\text { the acquisition of data; and } \\
\text { analysis or interpretation } \\
\text { of data }\end{array}$ \\
\hline $\begin{array}{l}\text { Hans-Peter } \\
\text { Hartung, MD, } \\
\text { PhD, FRCP }\end{array}$ & $\begin{array}{l}\text { Department of } \\
\text { Neurology, Medical } \\
\text { Faculty, Heinrich-Heine } \\
\text { University Düsseldorf, } \\
\text { Düsseldorf, Germany }\end{array}$ & $\begin{array}{l}\text { Drafting/revision of the } \\
\text { manuscript for content, } \\
\text { including medical writing } \\
\text { for content and analysis or } \\
\text { interpretation of data }\end{array}$ \\
\hline $\begin{array}{l}\text { Philipp } \\
\text { Albrecht, MD }\end{array}$ & $\begin{array}{l}\text { Department of } \\
\text { Neurology, Medical } \\
\text { Faculty, Heinrich-Heine } \\
\text { University Düsseldorf, } \\
\text { Düsseldorf, Germany }\end{array}$ & $\begin{array}{l}\text { Drafting/revision of the } \\
\text { manuscript for content, } \\
\text { including medical writing } \\
\text { for content; major role in } \\
\text { the acquisition of data; and } \\
\text { analysis or interpretation } \\
\text { of data }\end{array}$ \\
\hline
\end{tabular}

\section{References}

1. Leussink VI, Montalban X, Hartung HP. Restoring axonal function with 4aminopyridine: clinical efficacy in multiple sclerosis and beyond. CNS drugs 2018;32:637-651.

2. Horton $\mathrm{L}$, Conger $\mathrm{A}$, Conger $\mathrm{D}$, et al. Effect of 4-aminopyridine on vision in multiple sclerosis patients with optic neuropathy. Neurology 2013;80:1862-1866.

3. Morrow SA, Rosehart H, Johnson AM. The effect of Fampridine-SR on cognitive fatigue in a randomized double-blind crossover trial in patients with MS. Mult Scler Relat Disord 2017;11:4-9.

4. Broicher SD, Filli L, Geisseler O, et al. Positive effects of fampridine on cognition, fatigue and depression in patients with multiple sclerosis over 2 years. J Neurol 2018; 265:1016-1025.

5. Hayes KC, Blight AR, Potter PJ, et al. Preclinical trial of 4-aminopyridine in patients with chronic spinal cord injury. Paraplegia 1993;31:216-224. 
6. Iaci JF, Parry TJ, Huang Z, et al. Dalfampridine improves sensorimotor function in rats with chronic deficits after middle cerebral artery occlusion. Stroke 2013;44 1942-1950.

7. Trimmer JS, Rhodes KJ. Localization of voltage-gated ion channels in mammalian brain. Annu Rev Physiol 2004;66:477-519.

8. Rodríguez-Rangel S, Bravin $\mathrm{AD}$, Ramos-Torres $\mathrm{KM}$, Brugarolas $\mathrm{P}$, SánchezRodríguez JE. Structure-activity relationship studies of four novel 4-aminopyridine $\mathrm{K}(+)$ channel blockers. Sci Rep 2020;10:52.

9. Bostock H, Sears TA, Sherratt RM. The effects of 4-aminopyridine and tetraethylammonium ions on normal and demyelinated mammalian nerve fibres. J Physiol 1981;313:301-315.

10. Huynh W, Pickering H, Howells J, et al. Effect of fampridine on axonal excitability in multiple sclerosis. Clin Neurophysiol 2016;127:2636-2642.

11. DeCoursey TE, Chandy KG, Gupta S, Cahalan MD. Voltage-gated K+ channels in human T lymphocytes: a role in mitogenesis? Nature 1984;307:465-468.

12. Rus H, Pardo CA, Hu L, et al. The voltage-gated potassium channel Kv1.3 is highly expressed on inflammatory infiltrates in multiple sclerosis brain. Proc Natl Acad Sci U S A 2005; 102:11094-11099.

13. Wang X, Li G, Guo J, et al. Kv1.3 channel as a key therapeutic target for neuroinflammatory diseases: state of the art and beyond. Front Neurosci 2019;13:1393.

14. Wulff $\mathrm{H}$, Calabresi PA, Allie R, et al. The voltage-gated $\mathrm{Kv1} .3 \mathrm{~K}(+)$ channel in effector memory $\mathrm{T}$ cells as new target for MS. J Clin Invest 2003;111:1703-1713.

15. Burton JM, Bell CM, Walker SE, O'Connor PW. 4-aminopyridine toxicity with unintentional overdose in four patients with multiple sclerosis. Neurology 2008;71: 1833-1834.

16. Johnson NC, Morgan MW. An unusual case of 4-aminopyridine toxicity. J Emerg Med 2006;30:175-177.

17. Schwam E. Severe accidental overdose of 4-aminopyridine due to a compounding pharmacy error. J Emerg Med 2011;41:51-54.

18. Etemadifar M, Saboori M, Chitsaz A, et al. The effect of fampridine on the risk of seizure in patients with multiple sclerosis. Mult Scler Relat Disord 2020;43:102188.

19. Goodman AD, Cohen JA, Cross A, et al. Fampridine-SR in multiple sclerosis: randomized, double-blind, placebo-controlled, dose-ranging study. Mult Scler 2007; $13: 357-368$

20. Goodman $\mathrm{AD}$, Brown TR, Cohen JA, et al. Dose comparison trial of sustained-release fampridine in multiple sclerosis. Neurology 2008;71:1134-1141.

21. Goodman AD, Brown TR, Krupp LB, et al. Sustained-release oral fampridine in multiple sclerosis: a randomised, double-blind, controlled trial. Lancet 2009;373 $732-738$.

22. Goodman $\mathrm{AD}$, Brown TR, Edwards $\mathrm{KR}$, et al. A phase 3 trial of extended release oral dalfampridine in multiple sclerosis. Ann Neurol 2010;68:494-502.

23. Hupperts R, Lycke J, Short C, et al. Prolonged-release fampridine and walking and balance in MS: randomised controlled MOBILE trial. Mult Scler 2016;22:212-221.

24. Naujock M, Stanslowsky N, Bufler S, et al. 4-Aminopyridine induced activity rescues hypoexcitable motor neurons from amyotrophic lateral sclerosis patient-derived in duced pluripotent stem cells. Stem Cells 2016;34:1563-1575.

25. Franciosi S, Ryu JK, Choi HB, Radov L, Kim SU, McLarnon JG. Broad-spectrum effects of 4-aminopyridine to modulate amyloid beta1-42-induced cell signaling and functional responses in human microglia. J Neurosci 2006;26:11652-11664.

26. Li S, Wei D, Mao Z, et al. Design, synthesis, immunocytochemistry evaluation, and molecular docking investigation of several 4-aminopyridine derivatives as potential neuroprotective agents for treating Parkinson's disease. Bioorg Chem 2017;73:63-75.

27. Smith AJ, Tauskela JS, Stone TW, Smith RA. Preconditioning with 4-aminopyridine protects cerebellar granule neurons against excitotoxicity. Brain Res 2009;1294: $165-175$.

28. Tauskela JS, Aylsworth A, Hewitt M, Brunette E, Blondeau N. Failure and rescue of preconditioning-induced neuroprotection in severe stroke-like insults. Neuropharmacology 2016;105:533-542.

29. Tseng K-C, Li H, Clark A, et al. 4-Aminopyridine promotes functional recovery and remyelination in acute peripheral nerve injury. EMBO Mol Med 2016;8:1409-1420.

30. Ogita K, Okuda $\mathrm{H}$, Watanabe M, Nagashima R, Sugiyama C, Yoneda Y. In vivo treatment with the $\mathrm{K}+$ channel blocker 4-aminopyridine protects against kainateinduced neuronal cell death through activation of NMDA receptors in murine hippocampus. Neuropharmacology 2005;48:810-821.
31. Moriguchi K, Miyamoto K, Kusunoki S. 4-Aminopyridine ameliorates experimental autoimmune neuritis in Lewis rats. J Neuroimmunol 2017;305:72-74.

32. Schmalhofer WA, Bao J, McManus OB, et al. Identification of a new class of inhibitors of the voltage-gated potassium channel, Kv1.3, with immunosuppressant properties. Biochemistry 2002;41:7781-7794.

33. Varga Z, Csepany T, Papp F, et al. Potassium channel expression in human CD4+ regulatory and naïve $\mathrm{T}$ cells from healthy subjects and multiple sclerosis patients. Immunol Let 2009;124:95-101.

34. Jukkola P, Gu Y, Lovett-Racke AE, Gu C. Suppression of inflammatory demyelinaton and axon degeneration through inhibiting Kv3 channels. Front Mol Neurosci 2017; $10: 344$.

35. Moriguchi K, Miyamoto K, Fukumoto Y, Kusunoki S. 4-Aminopyridine ameliorates relapsing remitting experimental autoimmune encephalomyelitis in $\mathrm{SJL} / \mathrm{J}$ mice. J Neuroimmunol 2018;323:131-135.

36. Gobel K, Wedell J-H, Herrmann AM, et al. 4-Aminopyridine ameliorates mobility but not disease course in an animal model of multiple sclerosis. Exp Neurol 2013;248: $62-71$

37. Dietrich M, Koska V, Hecker C, et al. Protective effects of 4-aminopyridine in experimental optic neuritis and multiple sclerosis. Brain 2020;143:1127-1142.

38. Grimaldi M, Atzori M, Ray P, Alkon DL. Mobilization of calcium from intracellular stores, potentiation of neurotransmitter-induced calcium transients, and capacitative calcium entry by 4-aminopyridine. J Neurosci 2001;21:3135-3143.

39. van Diemen HA, Polman CH, Koetsier JC, van Loenen AC, Nauta JJ, Bertelsman FW. 4-Aminopyridine in patients with multiple sclerosis: dosage and serum level related to efficacy and safety. Clin Neuropharmacol 1993;16:195-204.

40. Davis FA, Stefoski D, Rush J. Orally administered 4-aminopyridine improves clinical signs in multiple sclerosis. Ann Neurol 1990;27:186-192.

41. Stefoski D, Davis FA, Faut M, Schauf CL. 4-Aminopyridine improves clinical signs in multiple sclerosis. Ann Neurol 1987;21:71-77.

42. Stefoski D, Davis FA, Fitzsimmons WE, Luskin SS, Rush J, Parkhurst GW. 4 Aminopyridine in multiple sclerosis: prolonged administration. Neurology 1991;41: 1344-1348

43. Jones RE, Heron JR, Foster DH, Snelgar RS, Mason RJ. Effects of 4-aminopyridine in patients with multiple sclerosis. J Neurol Sci 1983;60:353-362.

44. van Diemen HA, Polman CH, van Dongen TM, et al. The effect of 4-aminopyridine on clinical signs in multiple sclerosis: a randomized, placebo-controlled, double-blind, cross-over study. Ann Neurol 1992;32:123-130.

45. Polman CH, Bertelsmann FW, van Loenen AC, Koetsier JC. 4-aminopyridine in the treatment of patients with multiple sclerosis. Long-term efficacy and safety. Arch Neurol 1994;51:292-296.

46. Romani A, Bergamaschi R, Candeloro E, Alfonsi E, Callieco R, Cosi V. Fatigue in multiple sclerosis: multidimensional assessment and response to symptomatic treatment. Mult Scler 2004;10:462-468.

47. Rossini PM, Pasqualetti P, Pozzilli C, et al. Fatigue in progressive multiple sclerosis: results of a randomized, double-blind, placebo-controlled, crossover trial of oral 4-aminopyridine. Mult Scler 2001;7:354-358.

48. Hauser SL, Johnston SC. 4-aminopyridine: new life for an old drug. Ann Neurol 2010, 68:A8-A9.

49. Schwid SR, Petrie MD, McDermott MP, Tierney DS, Mason DH, Goodman AD Quantitative assessment of sustained-release 4-aminopyridine for symptomatic treatment of multiple sclerosis. Neurology 1997;48:817-821.

50. Goodman AD, Bethoux F, Brown TR, et al. Long-term safety and efficacy of dalfampridine for walking impairment in patients with multiple sclerosis: results of openlabel extensions of two Phase 3 clinical trials. Mult Scler 2015;21:1322-1331.

51. Hobart J, Ziemssen T, Feys P, et al. Assessment of clinically meaningful improvements in self-reported walking ability in participants with multiple sclerosis: results from the randomized, double-blind, phase III ENHANCE trial of prolonged-release fampridine. CNS drugs 2019;33:61-79.

52. Macdonell R, Nagels G, Laplaud DA, et al. Improved patient-reported health impact of multiple sclerosis: the ENABLE study of PR-fampridine. Mult Scler 2016;22: 944-954.

53. Noble M, Tseng K-CC, Li H, Elfar JC. 4-Aminopyridine as a single agent diagnostic and treatment for severe nerve crush injury. Mil Med 2019;184(suppl 1):379-385. 


\section{Neurology \\ Neuroimmunology \& Neuroinflammation}

Neuroprotective Properties of 4-Aminopyridine

Michael Dietrich, Hans-Peter Hartung and Philipp Albrecht

Neurol Neuroimmunol Neuroinflamm 2021;8;

DOI 10.1212/NXI.0000000000000976

This information is current as of March 2, 2021

\section{Updated Information \& Services}

References

Subspecialty Collections

Permissions \& Licensing

Reprints including high resolution figures, can be found at:

http://nn.neurology.org/content/8/3/e976.full.html

This article cites 53 articles, 5 of which you can access for free at: http://nn.neurology.org/content/8/3/e976.full.html\#\#ref-list-1

This article, along with others on similar topics, appears in the following collection(s):

Clinical trials Systematic review/meta analysis

http://nn.neurology.org//cgi/collection/clinical_trials_systematic_revie w_meta_analysis

Multiple sclerosis

http://nn.neurology.org//cgi/collection/multiple_sclerosis

Information about reproducing this article in parts (figures,tables) or in its entirety can be found online at:

http://nn.neurology.org/misc/about.xhtml\#permissions

Information about ordering reprints can be found online: http://nn.neurology.org/misc/addir.xhtml\#reprintsus

Neurol Neuroimmunol Neuroinflamm is an official journal of the American Academy of Neurology.

Published since April 2014, it is an open-access, online-only, continuous publication journal. Copyright

Copyright (C) 2021 The Author(s). Published by Wolters Kluwer Health, Inc. on behalf of the American

Academy of Neurology.. All rights reserved. Online ISSN: 2332-7812.

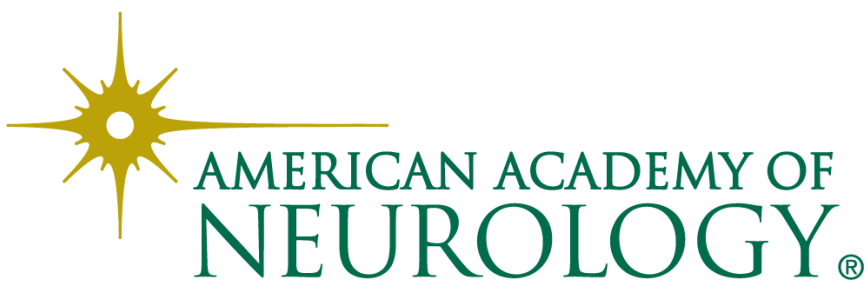

